\title{
PREHISTORIC ARCHAEOLOGY IN NORTHERN AUSTRALIA
}

\author{
By: Harry Allen*
}

The northern part of North Australia is not far from Java and Timor. There are great numbers of influences in the North Western part of Australia from Indonesian region. The coast alligator river area is 200 kilometres eats of Darwin, Northern Territory is now 60 kilometres from the coast to the mountain area. The plain area is flat and the water is saity, being ticlal on the coast. Further inland the river is fresh water. To day there are few mangroves in this area, but there is eviclence that mangroves were more widespread between 6.000-3.0C0 BP. During the wet season the coastal plain is flooded.

Mosi of the archaeological sites were rock shelters that were found at tiie rocky area at the edges of the mountain Occupation of open sites on the plain beginning about 2.000 years. On the inland plain, there is a river witin fresh water To day. the coast alligator river area has become a national park

During the dry season the Aboriginal people collects fresh water fish. turtle. yam and taro that grow from the surroundings. The mountain area was not very much occupations, the plain was covered with fresh water at the wet season which stopped people from gathering food there. The sites in the area are Malangangerr. Nawamoyn, Jimeri, excavated by $\mathrm{C}$ Schrire. The oldest site is Malangangerr, 26.000 years BP The sites are just simple rock shelter. To excavate the sites, the team must ask permission to the Aboriginal owner of the sites.

-Dr. H. Allen is educational staff at the Anthropology Department. University of Auckland New Zealand This article was part of his lecture given in Yogyakarta. August 26, 1986, held by the Department of Archaeniogy. Faculty of Letter. Gadjah mada University. The lecture took place at Balai Arkeologi Yogyakarta. 
Ngarradj Warde Djobkeng was excavated by $\mathrm{H}$. Allen and Nawalabia was excavated by R. Jones. A test excavation begin at 1972 and the final excavation was at 1977 on the bottom of the large hilly area at Ngarradj Warde Djobkeng by the author.

It is a small rock shelter near the mountain. The stratigraphy of the sites are just one metre of the shell and shell midden from 3.000 years BP, down bellow it was 1,5 metres sand with artifacts through from 5.000 until about 12.000 years BP.

Some other sites that were excavated ty Carmel White, another doctoral candidate, are shell midden. On the top of three sites dates 6.000-7.000; for the beginning of the shell midden dates 22.000-23.000; for the lower sand and another site are have $26.000 \mathrm{BP}$.

At 26.000 years BP the sea was 200 kilometres from the nowdays coast. So the area where I have been working now was then an inland area. The interesting artifacts in this site are ground adze-axes that people previously thought as a mark of Neolithic. But those axes were dated from 18.000 years BP. Those kind of axes were found in some sites. There is also a large flakes from $26.000-18.00 \mathrm{BP}$. Recently there were found small quartz flakes dated from $18.00-5.000$ years BP. After 5.000 BP small spear points are in the Middens, these spear points are like those from Sampungian sites from Java.

Rock paintings in the area are older than 5.000 years BP. The style of the rock paintings are just one colour. red ocher. The scene pf the paintings was depicted very lifely, movement animal such as mosquitos and fish. An interesting thing for the rock art is the portrait of different artifacts and spears, carrying bag, axes and boomerang. The modern rock art is different from the older rock art. The paintings are fish, human (woman), kangaroo. 
From 10.000 BP the sea level began to arise at the end of the Pleistocene period. By 5.000-6.000 BP. the sea levels were as the same as today. We have evidence that at $6.000 \mathrm{BP}$. there were very narrow mangroves. But the geologists found the evidence showing thick mangroves grew at $3.000 \mathrm{BP}$. It means that there was an environmental change since $3.000 \mathrm{BP}$. It is supported by the shell fish that was found in the shell midden. The shell fish are the mangrove shell-fish, relating to that period of the extensive mangrove.

The shell midden was associated with spear points. There is a very restricted distribution about this thing in that area. May be the Indonesian influences was responsible for this distribution of small scrapers, bone artifact (point). In my opinion, that bone point artifacts is similar to the Aborigin's bone point to day.

At 400 years BP (XVI Century) Makasar and Bugis's perahu began to come to the area to collected treepang parl shell. They influenced some of the Aborigin's culture in the area. The influences can be seen namely on their: perahu (canoes), tobaco's pipes and huts (tree house), harpoons, the model of the beard, and some ceremonies. 